


\section{AN EVALUATION OF HYDRATED \\ CALCIUM ALUMINATE COMPOUNDS AS ENERGY STORAGE MEDIA}

John B. Ings

Paul W. Brown

U.S. DEPARTMENT OF COMMERCE

National Bureau of Standards

National Engineering Laboratory

Center for Building Technology

Washington, DC 20234

June 1982

Prepared for:

U.S. Department of Energy

Office of Solar Heat Technologies

Conservation and Renewable Energy

Washington, DC 20585

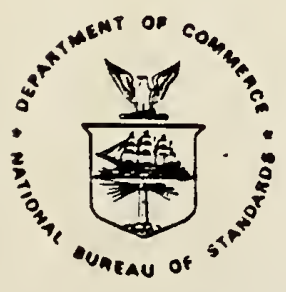

U.S. DEPARTMENT OF COMMERCE, Malcolm Baldrige, Secretary NATIONAL BUREAU OF STANDARDS, Ernest Ambler, Director 


\section{ABSTRACT}

Calcium aluminate hydrates and calcium aluminate hydrates containing other lons were investigated to determine the feasibility of their utilization as energy storage media. A series of these compounds were fabricated and analyzed for purity. The energy liberated on hydration of each compound was measured using conduction calorimetry and the dehydration temperature was measured using differential scanning calorimetry. Of the compounds investigated, $3 \mathrm{CaO} \cdot \mathrm{Al}_{2} \mathrm{O}_{3} 3 \mathrm{CaSO}_{4} 32 \mathrm{H}_{2} \mathrm{O}$ liberated the largest amount of energy upon rehydration. Initially, this value was about $100 \mathrm{cal} / \mathrm{g}$. However, after 18 cycles of hydration and dehydration this value drops to about $70 \mathrm{cal} / \mathrm{g}$.

Key Words: Calcium-aluminum hydrates; calorimetry; dehydrating; energy storage; rehydration; solar energy. 



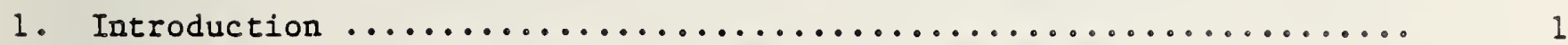

2. Crystal structure and Morphology ........................ 2

3. Compound Preparation ...............................

$3.14 \mathrm{CaO} \cdot \mathrm{Al}_{2} \mathrm{O}_{3} \cdot 13 \mathrm{H}_{2} \mathrm{O} \ldots \ldots \ldots \ldots \ldots \ldots \ldots \ldots \ldots \ldots \ldots \ldots \ldots \ldots \ldots \ldots \ldots \ldots \ldots . \ldots \ldots$

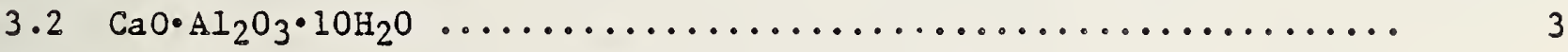

$3.32 \mathrm{CaO} \cdot \mathrm{Al}_{2} \mathrm{O}_{3} \cdot 8 \mathrm{H}_{2} \mathrm{O} \ldots \ldots \ldots \ldots \ldots \ldots \ldots \ldots \ldots \ldots \ldots \ldots \ldots \ldots \ldots \ldots \ldots \ldots$

$3.43 \mathrm{CaO} \cdot \mathrm{Al}_{2} \mathrm{O}_{3} \cdot 3 \mathrm{CaSO}_{4} \cdot 32 \mathrm{H}_{2} \mathrm{O} \ldots \ldots \ldots \ldots \ldots \ldots \ldots \ldots \ldots \ldots \ldots \ldots \ldots \ldots \ldots \ldots \ldots$

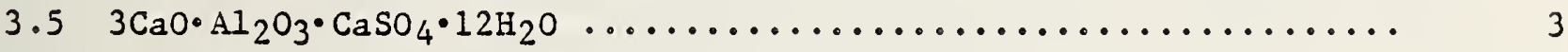

$3.6 \quad 3 \mathrm{CaO} \cdot \mathrm{Fe}_{2} \mathrm{O}_{3} \cdot 3 \mathrm{CaSO}_{4} \cdot 32 \mathrm{H}_{2} \mathrm{O} \ldots \ldots \ldots \ldots \ldots \ldots \ldots \ldots \ldots \ldots \ldots \ldots \ldots \ldots \ldots$

$3.7 \quad 3 \mathrm{CaO} \cdot \mathrm{Al}_{2} \mathrm{O}_{3} \cdot 3 \mathrm{CaCO}_{3} \cdot 32 \mathrm{H}_{2} \mathrm{O} \ldots \ldots \ldots \ldots \ldots \ldots \ldots \ldots \ldots \ldots \ldots \ldots \ldots \ldots \ldots$

$3.8 \quad 3 \mathrm{CaO}_{2} \cdot \mathrm{Al}_{2} \mathrm{O}_{3} \cdot \mathrm{CaCO}_{3} \cdot 11 \mathrm{H}_{2} \mathrm{O} \ldots \ldots \ldots \ldots \ldots \ldots \ldots \ldots \ldots \ldots \ldots \ldots \ldots \ldots \ldots$

$3.9 \quad 3 \mathrm{CaO} \cdot \mathrm{Al}_{2} \mathrm{O}_{3} \cdot 3 \mathrm{CaCl}_{2} \cdot 32 \mathrm{H}_{2} \mathrm{O} \ldots \ldots \ldots \ldots \ldots \ldots \ldots \ldots \ldots \ldots \ldots \ldots \ldots \ldots \ldots$

$3.103 \mathrm{CaO} \cdot \mathrm{Al}_{2} \mathrm{O}_{3} \cdot 3 \mathrm{CaCl}_{2} \cdot 11 \mathrm{H}_{2} \mathrm{O} \ldots \ldots \ldots \ldots \ldots \ldots \ldots \ldots \ldots \ldots \ldots \ldots \ldots \ldots \ldots$

4. Thermal Analysis $\ldots \ldots \ldots \ldots \ldots \ldots \ldots \ldots \ldots \ldots \ldots \ldots \ldots \ldots \ldots \ldots \ldots \ldots . \ldots \ldots \ldots$

5. Summary $\ldots \ldots \ldots \ldots \ldots \ldots \ldots \ldots \ldots \ldots \ldots \ldots \ldots \ldots \ldots \ldots \ldots \ldots \ldots$

6. Acknowledgment $\ldots \ldots \ldots \ldots \ldots \ldots \ldots \ldots \ldots \ldots \ldots \ldots \ldots \ldots \ldots \ldots \ldots \ldots \ldots$

7. References $\ldots \ldots \ldots \ldots \ldots \ldots \ldots \ldots \ldots \ldots \ldots \ldots \ldots \ldots \ldots \ldots \ldots \ldots \ldots \ldots \ldots$ 



\section{INTRODUCTION}

Calclum aluminate hydrates and calcium aluminate hydrates modifled by other lons were investigated to assess the feasibility of their utilization as phase change storage materials (PCM's). This was based on literature citations of low temperature reversible hydration-dehydration reactions involving only small changes in crystal structure rather than melting and freezing as is typical in salt hydrate PCM's.

Compounds were selected for further study if the literature indicated a dehydration reaction in the temperature range of 30 to $80^{\circ} \mathrm{C}$ and excluded if the hydration reactions were known to be irreversible. However, the hydration data in the literature were only valld for a preliminary screening of potential compounds for phase change storage media. This is due to the fact that the thermal decomposition behavior of these materials depends on the partial pressure of water vapor during dehydration. Almost all of the thermal dehydration measurements cited in the literature are for ambient air of unspecified water vapor pressure. Since compounds chosen for solar energy storage applications nay be used as slurries or under conditions of high relative humidity, the literature values for the thermal dehydration could only be used as a guide for selecting potential cement compounds for further investigation. In addition, little or no data on the kinetics of the hydration-dehydration reactions are available from the literature. These data were ascertained experimentally.

Based on the data from the literature the following components were selected for further study:

$4 \mathrm{CaO} \cdot \mathrm{Al}_{2} \mathrm{O}_{3} \cdot 13 \mathrm{H}_{2} \mathrm{O}$

$\mathrm{CaO} \cdot \mathrm{Al}_{2} \mathrm{O}_{3} \cdot 1 \mathrm{H}_{2} \mathrm{O}$

$2 \mathrm{CaO} \cdot \mathrm{Al}_{2} \mathrm{O}_{3} \cdot 8 \mathrm{H}_{2} \mathrm{O}$

$3 \mathrm{CaO} \cdot \mathrm{Al}_{2} \mathrm{O}_{3} \cdot 3 \mathrm{CaSO}_{4} \cdot 32 \mathrm{H}_{2} \mathrm{O}$

$3 \mathrm{CaO} \cdot \mathrm{Al}_{2} \mathrm{O}_{3} \cdot \mathrm{CaSO}_{4} \cdot 12 \mathrm{H}_{2} \mathrm{O}$

$3 \mathrm{CaO} \cdot \mathrm{Fe}_{2} \mathrm{O}_{3} \cdot 3 \mathrm{CaSO}_{4} \cdot 32 \mathrm{H}_{2} \mathrm{O}$

$3 \mathrm{CaO} \cdot \mathrm{Al}_{2} \mathrm{O}_{3} \cdot 3 \mathrm{CaCO}_{3} \cdot 32 \mathrm{H}_{2} \mathrm{O}$

$3 \mathrm{CaO} \cdot \mathrm{Al}_{2} \mathrm{O}_{3} \cdot \mathrm{CaCO}_{3} \cdot 11 \mathrm{H}_{2} \mathrm{O}$

$3 \mathrm{CaO} \cdot \mathrm{Al}_{2} \mathrm{O}_{3} \cdot 3 \mathrm{CaCl}_{2} \cdot 32 \mathrm{H}_{2} \mathrm{O}$

$3 \mathrm{CaO} \cdot \mathrm{Al}_{2} \mathrm{O}_{3} \cdot \mathrm{CaCl}_{2} \cdot 8 \mathrm{H}_{2} \mathrm{O}$ 
The methods used to prepare the various compounds are described subsequently. After preparation, the compounds were characterized for purity and completeness of reaction. Those not sultably pure were reformulated until a suitable purity was obtained. X-ray diffraction (XRD), and to a limited extent, scanning electron microscopy (SEM) were used for the characterization.

Prior to $x$-ray diffraction analysis of the compounds, a procedure was developed to prepare them for examination without changing their crystal structure as a result of drying, and for confirming that the XRD identification obtained for a dry powder was valid for the damp paste.

It was found that hydrated pastes could be prepared for $x$-ray diffraction analysis without altering their crystal structure by the following procedure: The slurry was filter pressed to form a filter cake of low water content (10 percent), followed by grinding the cake in absolute ethanol to form an alcohol-water-compound slurry. This was then vacuum dried at $30^{\circ} \mathrm{C}$ and a pressure of 91 kilopascals. The powder was then $x$-rayed and the patterns compared to those obtained by the original original investigators.

To ensure that the vacuum drying procedure had not altered the crystal structure of the compounds x-ray diffraction patterns were also obtained for undried samples. This was done by intergrinding the filter cakes with a small amount of glycerin and analyzing the damp paste. The glycerin acts as a viscous thickener to prevent preferred orientation often found when performing $x$-ray analyses on dry powders which have a platelet morphology. Although the peak to background ratios of the damp patterns were smaller than those of the dry patterns, it was confirmed that the drying procedure did not alter the crystal structure or cause excessive preferred orientation.

\section{COMPOUND PREPARATION}

\section{$3.14 \mathrm{CaO} \cdot \mathrm{Al}_{2} \mathrm{O}_{3} \cdot 13 \mathrm{H}_{2} \mathrm{O}$}

This compound was reported to reversibly dehydrate to $4 \mathrm{CaO} \cdot \mathrm{Al}_{2} \mathrm{O}_{3} \cdot 11 \mathrm{H}_{2} \mathrm{O}$ at about $50^{\circ} \mathrm{C}$ at a partial pressure of water vapor of 6 m $[1,2]$. On dehydration a slight change in crystal structure occurs due to the sinplification and deterioration of the order of stacking of the layers. This results in a decrease in the basal spacings as the compound goes from the 13 hydrate to the 11 hydrate and to the 7 hydrate at $120{ }^{\circ} \mathrm{C}[3] \cdot 4 \mathrm{CaO} \cdot \mathrm{Al}_{2} \mathrm{O}_{3} \cdot 13 \mathrm{H}_{2} \mathrm{O}$ was prepared by the stochiometric addition of freshly ignited CaO to a metastable monocalcium aluminate solution and shaking the mixture for several days at $25^{\circ} \mathrm{C}$. Care was taken to exclude $\mathrm{CO}_{2}$ during preparation. The compound fabricated was a mixture of $\alpha$ and $\beta$ polymorphic forms of $4 \mathrm{CaO} \cdot \mathrm{Al}_{2} \mathrm{O}_{3} \cdot 13 \mathrm{H}_{2} \mathrm{O}$ and contained a few percent of unreacted $\mathrm{Ca}(\mathrm{OH})_{2}$. The two polymorphic forms differ only by a slight difference in the packing of the crystal lattice. There is little difference in stability between the two forms. As $\mathrm{Ca}(\mathrm{OH})_{2}$ does not dehydrate in the temperature range under investigation, the presence of a small amount was not deemed detrimental. 


\section{$3.2 \mathrm{CaO} \cdot \mathrm{Al}_{2} \mathrm{O}_{3} \cdot 10 \mathrm{H}_{2} \mathrm{O}$}

The compound $\mathrm{CaO} \cdot \mathrm{Al}_{2} \mathrm{O}_{3} \cdot 10 \mathrm{H}_{2} \mathrm{O}$ was reported to decompose to an amorphous calcium aluminate if heated between 50 and $75^{\circ} \mathrm{C}$ in alr [4]. If heated to $110^{\circ} \mathrm{C}$ in the presence of water vapor $\mathrm{CaO} \cdot \mathrm{Al}_{2} \mathrm{O}_{3} \cdot 10 \mathrm{H}_{2} \mathrm{O}$ irreversibly converts to a mixture of $3 \mathrm{Ca} \cdot \mathrm{Al}_{2} \mathrm{O}_{3} \cdot 6 \mathrm{H}_{2} \mathrm{O}$ and $\mathrm{Al}_{2} \mathrm{O}_{3} \cdot 3 \mathrm{H}_{2} \mathrm{O}$ [4]. The reversibility of the the reaction of $\mathrm{CaO} \cdot \mathrm{Al}_{2} \mathrm{O}_{3} \cdot \mathrm{OH}_{2} \mathrm{O}$ to amorphous reaction product was not cited. $\mathrm{CaO} \cdot \mathrm{Al}_{2} \mathrm{O}_{3} \cdot 10 \mathrm{H}_{2} \mathrm{O}$ is the main reaction product of hydrated calcium aluminate cement and was prepared by hydrating a commercially available calcium aluminate cement to completion.

$X$-ray diffraction analysis of the compound $\mathrm{CaO} \cdot \mathrm{Al}_{2} \mathrm{O}_{3} \cdot 10 \mathrm{H}_{2} \mathrm{O}$, revealed the presence of minor amounts of $4 \mathrm{CaO} \cdot \mathrm{Al}_{2} \mathrm{O}_{3} \cdot 13 \mathrm{H}_{2} \mathrm{O}$ due to the relatively impure commercial calcium cement used as a reactant. It was, however, possible to account for the $4 \mathrm{CaO} \cdot \mathrm{Al}_{2} \mathrm{O}_{3} \cdot 13 \mathrm{H}_{2} \mathrm{O}$ contribution to the total heats of transition measured [5].

\section{$3.32 \mathrm{CaO} \cdot \mathrm{Al}_{2} \mathrm{O}_{3} \cdot 8 \mathrm{H}_{2} \mathrm{O}$}

The compound $2 \mathrm{CaO} \cdot \mathrm{Al}_{2} \mathrm{O}_{3} \cdot 8 \mathrm{H}_{2} \mathrm{O}$ was reported to reversibly dehydrate to $2 \mathrm{CaO} \cdot \mathrm{Al}_{2} \mathrm{O}_{3} \cdot 7 \cdot 5 \mathrm{H}_{2} \mathrm{O}$ at room temperature when dried in air having 34 percent $\mathrm{RH}$ and to further dehydrate to $2 \mathrm{CaO} \cdot \mathrm{Al}_{2} \mathrm{O}_{3} \cdot 5 \mathrm{H}_{2} \mathrm{O}$ when heated to $102^{\circ} \mathrm{C}[2]$. Both the 7.5 and 5 hydrate compounds will readily convert to the 8 hydrate when exposed to a damp atmosphere. A corresponding change in the $x$-ray diffraction pattern for the longest basal spacing of $10.7 \AA$ or $10.4 \AA$ depending on the polymorphic form of the 8 hydrate, to $10.6 \AA$ for the 7.5 hydrate resulted, indicating some structural rearrangement had occurred. The compound was prepared using a method similar to that used to prepare $4 \mathrm{CaO} \cdot \mathrm{Al}_{2} \mathrm{O}_{3} \cdot 13 \mathrm{H}_{2} \mathrm{O}$. However, $2 \mathrm{CaO} \cdot \mathrm{Al}_{2} \mathrm{O}_{3} \cdot 8 \mathrm{H}_{2} \mathrm{O}$ was found to be unstable with respect to $4 \mathrm{CaO} \cdot \mathrm{Al}_{2} \mathrm{O}_{3} \cdot 13 \mathrm{H}_{2} \mathrm{O}$ and work on this compound was discontinued.

\section{$3.43 \mathrm{CaO} \cdot \mathrm{Al}_{2} \mathrm{O}_{3} \cdot 3 \mathrm{CaSO}_{4} \cdot 32 \mathrm{H}_{2} \mathrm{O}$}

The compound $3 \mathrm{CaO} \cdot \mathrm{Al}_{2} \mathrm{O}_{3} \cdot 3 \mathrm{CaSO}_{4} \cdot 32 \mathrm{H}_{2} \mathrm{O}$ (ettringite) was reported to dehydrate to $3 \mathrm{CaO} \cdot \mathrm{Al}_{2} \mathrm{O}_{3} \cdot 3 \mathrm{CaSO}_{4} \cdot 32 \mathrm{OH}_{2} \mathrm{O}$ at $60{ }^{\circ} \mathrm{C}$ at an unspecified partial pressure of water vapor [5]. X-ray diffraction has shown that very little change occurs in the crystal structure during this dehydration. The dehydration reactions we re found to be reversible down to the 7 hydrate form [7]. Ettringite forms as the result of slow reaction of $3 \mathrm{CaO} \cdot \mathrm{Al}_{2} \mathrm{O}_{3}$ with $\mathrm{CaSO}_{4} \cdot 2 \mathrm{H}_{2} \mathrm{O}$ (gypsum) in solution. No secondary phases were detected in the $3 \mathrm{CaO} \cdot \mathrm{Al}_{2} \mathrm{O}_{3} \cdot 3 \mathrm{CaSO} \mathrm{C}_{4} \cdot 32 \mathrm{H}_{2} \mathrm{O}$ fabricated in this manner. SEM analysis revealed well formed needles about 1 im in length.

\section{$3.53 \mathrm{CaO} \cdot \mathrm{Al}_{2} \mathrm{O}_{3} \cdot \mathrm{CaSO}_{4} \cdot 12 \mathrm{H}_{2} \mathrm{O}$}

$3 \mathrm{CaO} \cdot \mathrm{Al}_{2} \mathrm{O}_{3} \cdot \mathrm{CaSO}_{4} \cdot 12 \mathrm{H}_{2} \mathrm{O}$ gradually loses water on heating transforming to $3 \mathrm{CaO} \cdot \mathrm{Al}_{2} \mathrm{O}_{3} \cdot \mathrm{CaSO}_{4} \cdot 7 \mathrm{H}_{2} \mathrm{O}$ by $110^{\circ} \mathrm{C}[7,8]$. No information was avallable on the reversibility of the reactions. $3 \mathrm{CaO} \cdot \mathrm{Al}_{2} \mathrm{O}_{3} \cdot \mathrm{CaSO}_{4} \cdot 12 \mathrm{H}_{2} \mathrm{O}$ was prepared by adding a saturated $\mathrm{Ca}(\mathrm{OH})_{2}$ solution containing sufficient $\mathrm{CaSO}_{4} \cdot 2 \mathrm{H}_{2} \mathrm{O}$ to obtain a $\mathrm{CaSO}_{4} / \mathrm{Al}_{2} \mathrm{O}_{3}$ ratio of unity to a metastable calcium aluminate solution. 
$3 \mathrm{CaO} \cdot \mathrm{Al}_{2} \mathrm{O}_{3} \cdot \mathrm{CaSO}_{4} \cdot 12 \mathrm{H}_{2} \mathrm{O}$ prepared in this manner was found to contain a small amount of ettringite. However, since a pure ettringite sample was available, the contribution of ettringite on the total heat of transition could be measured.

\section{$3.63 \mathrm{CaO} \cdot \mathrm{Fe}_{2} \mathrm{O}_{3} \cdot 3 \mathrm{CaSO}_{4} \cdot 32 \mathrm{H}_{2} \mathrm{O}$}

The thermal dehydration behavior of $3 \mathrm{CaO} \cdot \mathrm{Fe}_{2} \mathrm{O}_{3} \cdot 3 \mathrm{CaSO}_{4} \cdot 32 \mathrm{H}_{2} \mathrm{O}$ has been shown to be similar to that of ettringite [7], as would be expected due to the similiarity of their crystal structures. $3 \mathrm{CaO} \cdot \mathrm{Fe}_{2} \mathrm{O}_{3} \cdot 3 \mathrm{CaSO}_{4} \cdot 32 \mathrm{H}_{2} \mathrm{O}$ was prepared by mixing a solution of iron alum with $\mathrm{Ca}(\mathrm{OH})_{2}$ in suitable proportions [11]. SEM analysis revealed well formed crystals which exhibited a blocky habit.

\section{$3.73 \mathrm{CaO} \cdot \mathrm{Al}_{2} \mathrm{O}_{3} \cdot 3 \mathrm{CaCO}_{3} \cdot 32 \mathrm{H}_{2} \mathrm{O}$}

The dehydration of this compound initiates at about $75^{\circ} \mathrm{C}$ and is essentially complete at $135{ }^{\circ} \mathrm{C}[9]$. $3 \mathrm{CaO} \cdot \mathrm{Al}_{2} \mathrm{O}_{3} \cdot 3 \mathrm{CaCO}_{3} \cdot 32 \mathrm{H}_{2} \mathrm{O}$ was prepared by dissolving $\mathrm{CaO}$ in an aqueous solution of sucrose. After the solution clarified by settling it was decanted into a calcium aluminate solution followed by the addition of an ammonium bicarbonate solution. $3 \mathrm{CaO} \cdot \mathrm{Al}_{2} \mathrm{O}_{3} \cdot 3 \mathrm{CaCO}_{3} \cdot 32 \mathrm{H}_{2} \mathrm{O}$ formed as a flocculant precipitate.

\section{$3.83 \mathrm{CaO} \cdot \mathrm{Al}_{2} \mathrm{O}_{3} \cdot \mathrm{CaCO}_{3} \cdot 11 \mathrm{H}_{2} \mathrm{O}$}

This compound was reported to dehydrate over a temperature range from 75 to $150{ }^{\circ} \mathrm{C}[10]$. It was produced by the slow reaction of calcium aluminate cement with $\mathrm{Ca}(\mathrm{OH})_{2}$ and $\mathrm{CaCO}_{3}$ in aqueous solution. SEM analysis revealed the $3 \mathrm{CaO} \cdot \mathrm{Al}_{2} \mathrm{O}_{3} \cdot \mathrm{CaCO}_{3} \cdot 1 \mathrm{H}_{2} \mathrm{O}$ to form as thin hexagonal plates, approximately $2 \mu \mathrm{m}$ in width.

\section{$3.93 \mathrm{CaO} \cdot \mathrm{Al}_{2} \mathrm{O}_{3} \cdot 3 \mathrm{CaCl}_{2} \cdot 32 \mathrm{H}_{2} \mathrm{O}$}

This compound was reported to initiate dehydration at about $0{ }^{\circ} \mathrm{C}$ and to decompose above $20^{\circ} \mathrm{C}[13] . \quad 3 \mathrm{CaO} \cdot \mathrm{Al}_{2} \mathrm{O}_{3} \cdot 3 \mathrm{CaCl}_{2} \cdot 32 \mathrm{H}_{2} \mathrm{O}$ was formed by the reaction of $3 \mathrm{CaO} \cdot \mathrm{Al}_{2} \mathrm{O}_{3}$ with a $\mathrm{CaCl}_{2}$ solution at $-10^{\circ} \mathrm{C}$. On heating $3 \mathrm{CaO} \cdot \mathrm{Al}_{2} \mathrm{O}_{3} \cdot 3 \mathrm{CaCO}_{3} \cdot 32 \mathrm{H}_{2} \mathrm{O}$ to room temperature, it was confirmed that this compound decomposed to $2 \mathrm{CaO} \cdot \mathrm{Al}_{2} \mathrm{O}_{3} \cdot \mathrm{CaCl}_{2} \cdot 8 \mathrm{H}_{2} \mathrm{O}$. Further work on this compound was dropped due to its instability.

\section{$3.103 \mathrm{CaO} \cdot \mathrm{Al}_{2} \mathrm{O}_{3} \cdot \mathrm{CaCl}_{2} \cdot 8 \mathrm{H}_{2} \mathrm{O}$}

This compound was reported to initiate dehydration at about $120{ }^{\circ} \mathrm{C}$ [13]. $3 \mathrm{CaO} \cdot \mathrm{Al}_{2} \mathrm{O}_{3} \cdot \mathrm{CaCl}_{2} \cdot 8 \mathrm{H}_{2} \mathrm{O}$ was produced by the slow reaction of a commercial calcium aluminate cement with $\mathrm{Ca}(\mathrm{OH})_{2}$ and $\mathrm{CaCl}_{2}$. SEM analysis revealed this compound to form as $1 \mu \mathrm{m}$ plates in width 
Two schemes were investigated for using hydrated calcium aluminate compounds to store energy. The first involved storing the compounds as wet pastes in sealed containers. As the containers are heated the compounds expel waters of hydration from their crystal structures and absorb energy as latent heat. Upon lowering the temperature of the containers, the compounds rehydrate and release the latent heat.

The compounds were tested using a differential scanning calorimeter to determine the temperature at which dehydration occurred and to determine the associated latent heats. The key feature of the differential scanning calorimetric (DSC) technique was the use of hermetically sealed sample pans which prevented the samples from dessicating during heating. All the compounds formulated for this study were tested using this method. Of these compounds only $3 \mathrm{CaO}^{\circ} \mathrm{Fe}_{2} \mathrm{O}_{3} \cdot 3 \mathrm{CaSO}_{4}$. $32 \mathrm{H}_{2} \mathrm{O}, \mathrm{CaO} \cdot \mathrm{Al}_{2} \mathrm{O}_{3} \cdot 1 \mathrm{OH}_{2} \mathrm{O}$ and $3 \mathrm{CaO} \cdot \mathrm{Al}_{2} \mathrm{O}_{3} \cdot \mathrm{CaCO}_{3} \cdot 11 \mathrm{H}_{2} \mathrm{O}$ exhibited reversible hydration reactions at temperatures below $140{ }^{\circ} \mathrm{C}$. $3 \mathrm{CaO} \cdot \mathrm{Fe}_{2} \mathrm{O}_{3} \cdot 3 \mathrm{CaSO}_{4} \cdot 32 \mathrm{H}_{2} \mathrm{O}$ exhibited a reversible hydration reaction at $64^{\circ} \mathrm{C}$ but the latent heat of transition was only $5 \mathrm{cal} / \mathrm{g}$. Similarly, $\mathrm{CaO} \cdot \mathrm{Al}_{2} \mathrm{O}_{3} \cdot 10 \mathrm{H}_{2} \mathrm{O}$ and $3 \mathrm{CaO} \cdot \mathrm{Al}_{2} \mathrm{O}_{3} \cdot \mathrm{CaCO}_{3} \cdot 1 \mathrm{H}_{2} \mathrm{O}$ had reversible reactions at 77 and $127{ }^{\circ} \mathrm{C}$, respectively, with heats of transition of 6 and $24 \mathrm{cal} / \mathrm{g}$. As a consequence of these results, it was concluded that this method of energy storage using cement compounds was not feasible.

A second method for using hydrated cement compounds to store energy involved removing the water of hydration by drying the compounds at a suitable temperature. Upon the subsequent addition of water, the compounds would rehydrate and release their latent heats of hydration. This methodology involved the determination of the temperature at which these compounds would dehydrate in dry air. This was accomplished by testing the hydrated compounds in a DSC utilizing a cell with a pinhole opening which allowed the escape of hydration water. The thermogram for $3 \mathrm{CaO} \cdot \mathrm{Al}_{2} \mathrm{O}_{3} \cdot 3 \mathrm{CaSO}_{4} \cdot 32 \mathrm{H}_{2} \mathrm{O}$ is shown in figure 1 while that for $3 \mathrm{CaO} \cdot \mathrm{Fe}_{2} \mathrm{O}_{3} \cdot 3 \mathrm{CaSO}_{4} \cdot 32 \mathrm{H}_{2} \mathrm{O}$ is shown in figure 2. Three endothermic dehydration peaks are observed for $3 \mathrm{CaO} \cdot \mathrm{Al}_{2} \mathrm{O}_{3} \cdot 3 \mathrm{CaSO}_{4} \cdot 32 \mathrm{H}_{2} \mathrm{O}$. The first peak shows an onset near $67{ }^{\circ} \mathrm{C}$ and a small latent heat of dehydration. The onset of the second peak occurs near $90^{\circ} \mathrm{C}$ and also shows as small heat of dehydration. The onset temperature of the third peak is about $100{ }^{\circ} \mathrm{C}$ and a relatively large heat of dehydration is observed. The thermogram for $3 \mathrm{CaO} \cdot \mathrm{Fe}_{2} \mathrm{O}_{3} \cdot 3 \mathrm{CaSO}_{4} \cdot 32 \mathrm{H}_{2} \mathrm{O}$, figure 2 , shows one endothermic dehydration peak with an onset near $95^{\circ} \mathrm{C}$.

Once the dehydration temperatures were determined using differential scanning calorimetry the compounds were heated to temperatures above their dehydration temperatures and their latent heats of hydration measured using a conduction calorimeter. In this technique, the dried cement compound was placed in the calorimeter, equilibrium established, and excess distilled water injected into the calorimeter to hydrate the compound. The heat released as the compound rehydrated was integrated to give the latent heat in cal/g. In addition, information on the rate of heat release was also obtained. 


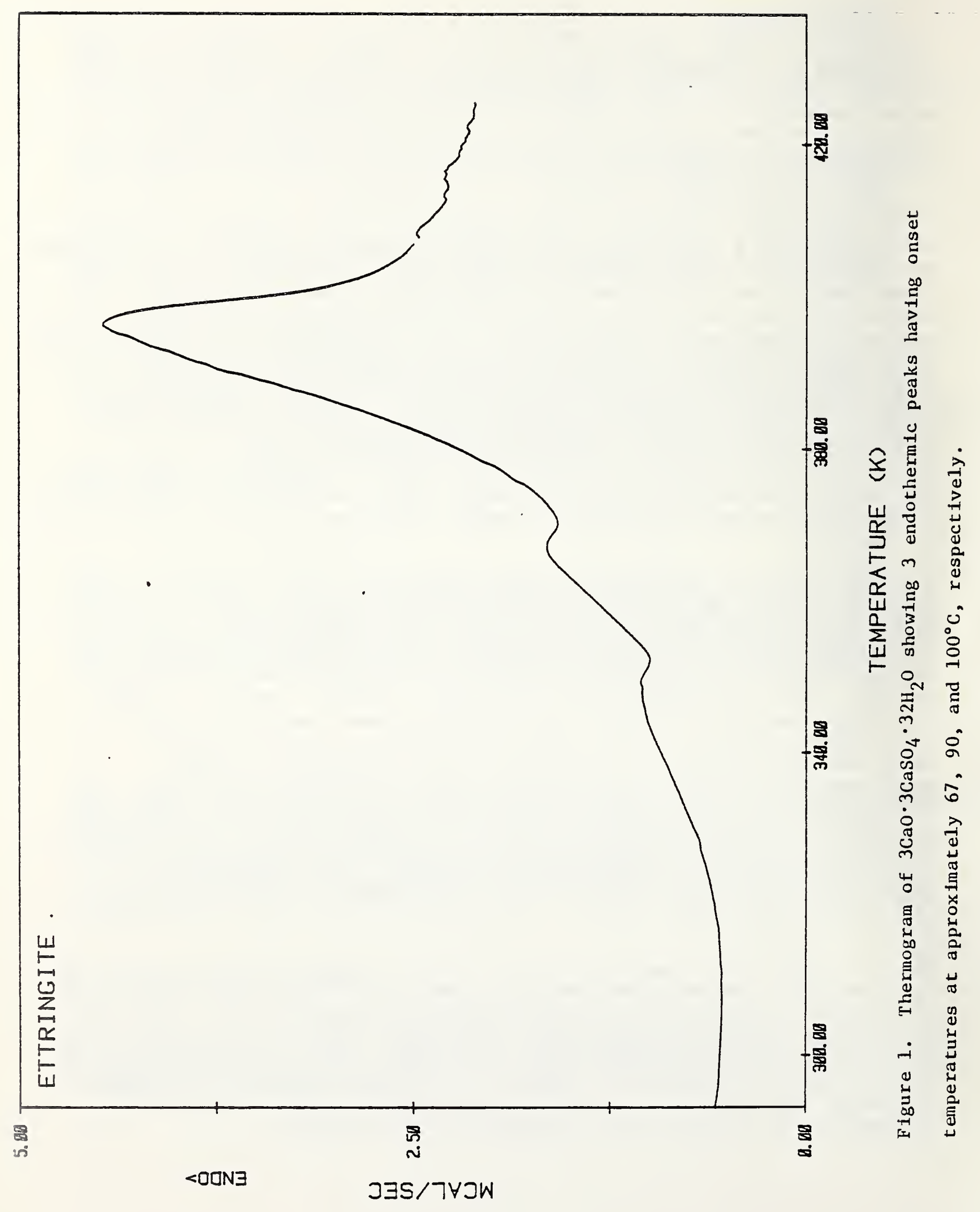




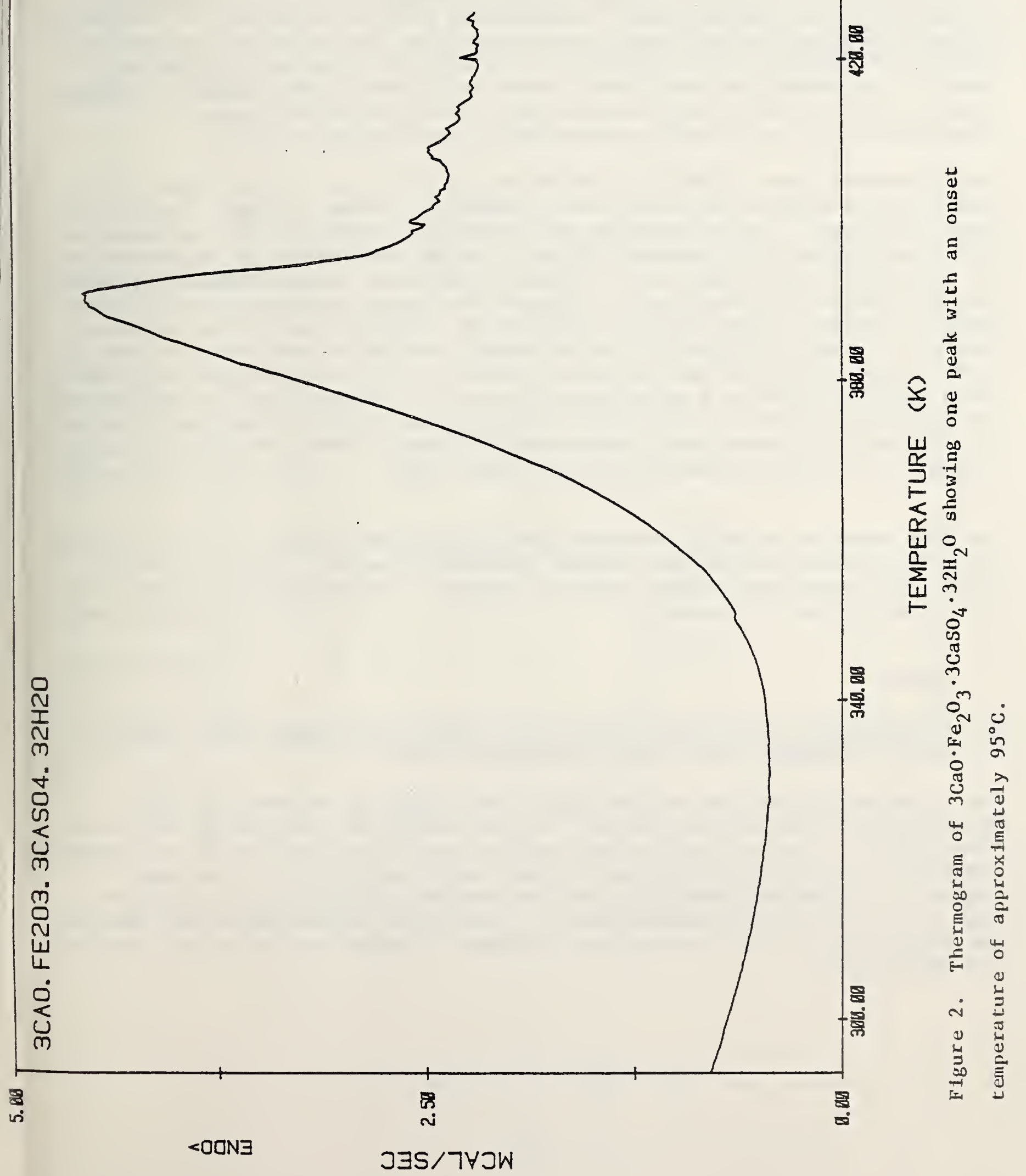


Table 1 lists the onsets of the dehydration peaks as measured by differential scanning calorimetry and the latent heats as measured by conduction calorimetry for the compounds investigated. The temperatures at which the compounds were dehydrated are also listed. The dehydration temperature is the temperature at which the compounds were dried for 24 hours prior to rehydration. For most of the compounds the latent heats were either too low or the temperature required to dehydrate the compounds was too high for practical application. However, compounds with significant latent heats were studied further. These were $3 \mathrm{CaO} \cdot \mathrm{Al}_{2} \mathrm{O}_{3} \cdot 3 \mathrm{CaSO}_{4} \cdot 32 \mathrm{H}_{2} \mathrm{O}$ and $3 \mathrm{CaO} \cdot \mathrm{Fe}_{2} \mathrm{O}_{3} \cdot 3 \mathrm{CaSO}_{4} \cdot 32 \mathrm{H}_{2} \mathrm{O}$ with heats of rehydration of 97 and $43 \mathrm{cal} / \mathrm{g}$ respectively after drying at $100^{\circ} \mathrm{C}$.

These compounds were alternately dehydrated at $100{ }^{\circ} \mathrm{C}$ for 24 hours and rehydrated to measure the latent heat released on thermal cycling. Results are shown in figure 3. Both compounds were observed to undergo a slow decrease in total heat release with repeated cycling. An SEM examination of the morphology of $3 \mathrm{CaO} \cdot \mathrm{Al}_{2} \mathrm{O}_{3} \cdot 3 \mathrm{CaSO}_{4} \cdot 32 \mathrm{H}_{2} \mathrm{O}$ after repeated rehydration did not suggest a reason for the decrease in latent heat. Although the latent heats decreased with the number of drying cycles, the time required for complete heat release remained constant. $3 \mathrm{CaO} \cdot \mathrm{Al}_{2} \mathrm{O}_{3} \cdot 3 \mathrm{CaSO}_{4} \cdot 32 \mathrm{H}_{2} \mathrm{O}$ was readily wetted by water and its rate of heat release was faster than the time constant of the calorimeter. This compound rapidly heated to a temperature of up to $60^{\circ} \mathrm{C}$ giving off the majority of its latent heat within 10 seconds. $3 \mathrm{CaO} \cdot \mathrm{Fe}_{2} \mathrm{O}_{3} \cdot 3 \mathrm{CaSO}_{4} \cdot 32 \mathrm{H}_{2} \mathrm{O}$ also readily wetted by water but its rate of heat release was noticeably slower requiring at least a minute to release the majority of its latent heat.

The time required to fully dehydrate $3 \mathrm{CaO} \cdot \mathrm{Al}_{2} \mathrm{O}_{3} \cdot 3 \mathrm{CaSO}{ }_{4} \cdot 32 \mathrm{H}_{2} \mathrm{O}$ at $100{ }^{\circ} \mathrm{C}$ in order to to achieve the maximum heat release on rehydration was 3 days. Drying 24 hr at this temperature yielded about 95 percent of the maximum drying while for 3 hr yielded about 75 percent.

\section{SUMMARY}

Of the compounds investigated in this study $3 \mathrm{CaO} \cdot \mathrm{Al}_{2} \mathrm{O}_{3} \cdot 3 \mathrm{CaSO}_{4} \cdot 32 \mathrm{H}_{2} \mathrm{O}$, appears to be the most promising phase change storage material.

The potential for the use of $3 \mathrm{CaO} \cdot \mathrm{Al}_{2} \mathrm{O}_{3} \cdot 3 \mathrm{CaSO}_{4} \cdot 32 \mathrm{H}_{2} \mathrm{O}$ as an energy storage medium results from several factors: 1) the ability to store energy at ambient temperature; 2) low corrosivity and toxicity; and 3) the low cost of the compound. Impure $3 \mathrm{CaO} \cdot \mathrm{Al}_{2} \mathrm{O}_{3} \cdot 3 \mathrm{CaSO}_{4} \cdot 32 \mathrm{H}_{2} \mathrm{O}$ may be made using waste products from coal combustion including lignitic fly ash and scrubber sludge [12]. The disadvantages to the use of this compound are: 1) relatively high temperatures required for dehydration; and 2) the observed decrease in latent heat on cyclic hydration and dehydration. 
Table 1. Latent Heats of Hydration for Selected Compounds.

\begin{tabular}{|c|c|c|c|}
\hline Compound & $\begin{array}{l}\text { Peak Onset } \\
\text { Temperature }\end{array}$ & $\begin{array}{l}\text { Dehydration } \\
\text { Temperature }\end{array}$ & $\begin{array}{l}\text { Latent heat of } \\
\text { Hydration cal/g }\end{array}$ \\
\hline \multirow[t]{4}{*}{$3 \mathrm{CaO} \cdot \mathrm{Al}_{2} \mathrm{O}_{3} \cdot 3 \mathrm{CaSO}_{4} \cdot 32 \mathrm{H}_{2} \mathrm{O}$} & - & $30{ }^{\circ} \mathrm{C}$ & 2 \\
\hline & $67^{\circ} \mathrm{C}$ & 80 & 8 \\
\hline & 90 & 100 & 97 \\
\hline & 100 & 140 & 102 \\
\hline \multirow[t]{2}{*}{$3 \mathrm{CaO} \cdot \mathrm{Fe}_{2} \mathrm{O}_{3} \cdot 3 \mathrm{CaSO}_{4} \cdot 32 \mathrm{H}_{2} \mathrm{O}$} & 95 & 100 & 43 \\
\hline & 95 & 140 & 49 \\
\hline \multirow[t]{2}{*}{$3 \mathrm{CaO} \cdot \mathrm{Al}_{2} \mathrm{O}_{3} \cdot \mathrm{CaCl}_{2} \cdot 8 \mathrm{H}_{2} \mathrm{O}$} & 75 & 80 & 2 \\
\hline & 75 & 110 & 29 \\
\hline \multirow[t]{3}{*}{$3 \mathrm{CaO} \cdot \mathrm{Al}_{2} \mathrm{O}_{3} \cdot \mathrm{CaCO}_{3} \cdot 11 \mathrm{H}_{2} \mathrm{O}$} & 118 & 60 & 12 \\
\hline & 118 & 110 & 12 \\
\hline & 118 & 160 & 26 \\
\hline $3 \mathrm{CaO} \cdot \mathrm{Al}_{2} \mathrm{O}_{3} \cdot \mathrm{CaSO}_{4} \cdot 12 \mathrm{H}_{2} \mathrm{O}$ & 57 & 100 & 14 \\
\hline $\mathrm{CaO} \cdot \mathrm{Al}_{2} \mathrm{O}_{3} \cdot 13 \mathrm{H}_{2} \mathrm{O}$ & 77 & 100 & 5 \\
\hline${ }^{\star} \mathrm{CaO} \cdot \mathrm{Al}_{2} \mathrm{O}_{3} \cdot 1 \mathrm{OH}_{2} \mathrm{O}$ & 65 & 75 & 20 \\
\hline
\end{tabular}

*Not reversible. 


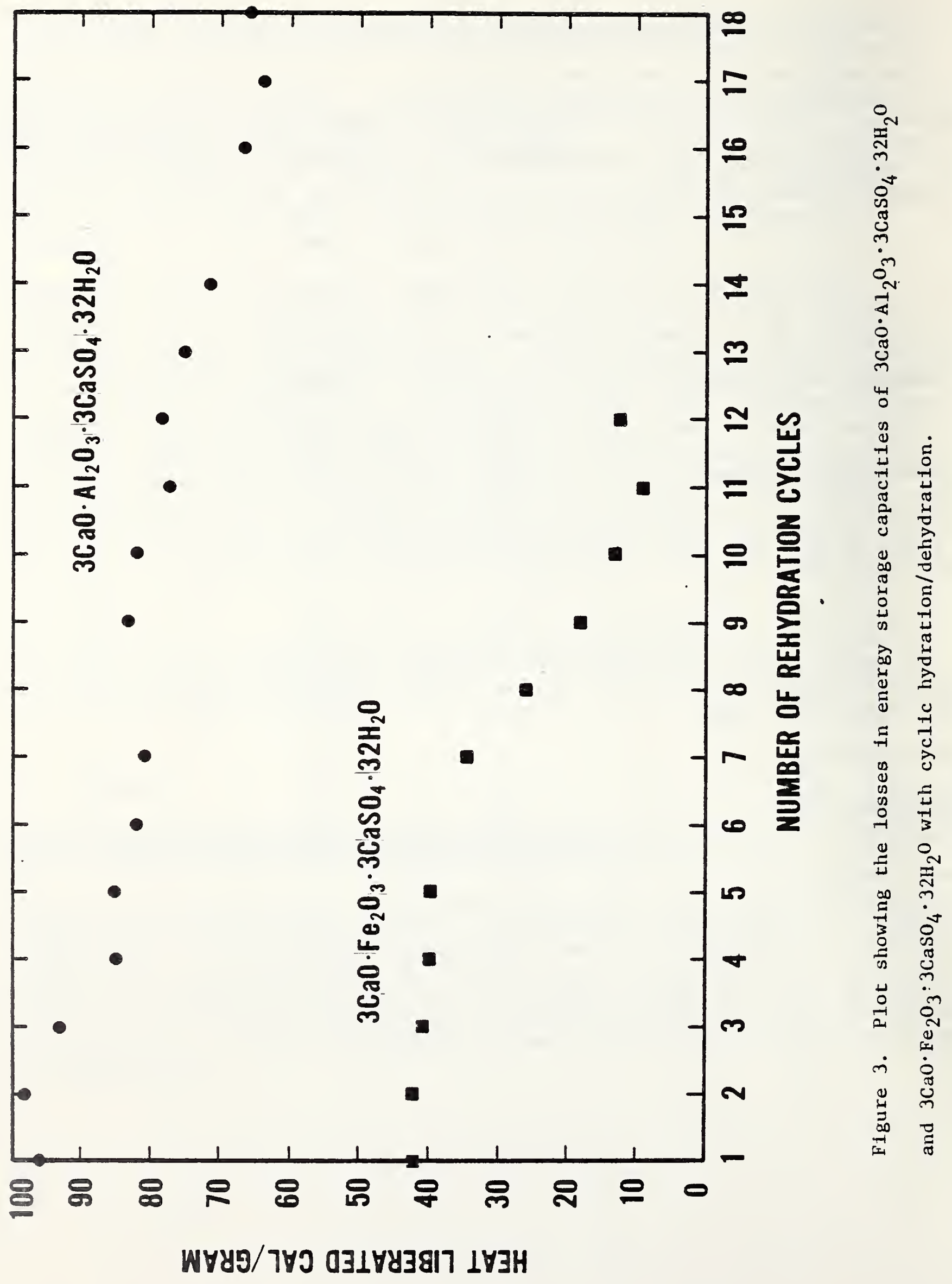


6. ACXNOWLEDGMENT

The authors gratefully acknowledge the U.S. Department of Energy, Office of Solar Heat Technologies, Conservation, and Renewable Energy for supporting this investigation.

7. REFERENCES

1. Buttler, F. G., Dent Glasser, L. S., and Taylor, H. R. W., J. Amer. Cer. Soc., 42, 121 (1959).

2. Roberts, M. H., J. Appl. Chem., I, 543 (1957).

3. Jones, F. E., Chemistry of Cement, Proceedings of the Fourth International Symposium, Washington, 1960, p. 204. National Bureau of Standards Monograph 43, U.S. Department of Commerce.

4. Schneider, S., J. Amer. Cer. Soc., 42, 184 (1959).

5. Berman, H. A. and Newman, E. S., Ibid. Ief 3, p. 247.

6. Lerch, W., Ashton, F. W., and Bogue, R. H., J. Res. Nat. Bur. Stand. 2 , 715, (1929).

7. Midgley, H. G. and Rosaman, D., Ibid. ref. 3, P. 259.

8. Turrizlani, R., in The Chemistry of Cements, Vo1. 1, 262, Academic Press, London (1964).

9. Carlson, E. T. and Berman, H. A., J. Res. Nat. Bur. Stand., 64A, 333 (1960).

10. Turriziani, R. and Schippa, G., Ric. Sci., 26, 2792 (1956).

11. Jones, F. E., J. Phys. Chem., 49, 344 (1945).

12. Ings, J. B. and Bauer, W. H., Bull. Amer. Cer. Soc., 60, 474 (1981).

13. Serb-Serbina, N. N., Savina, Y. A., and Zhurino, V. S., Dokl. Akad. Novk. S.S.S.R., 111, 659 (1955). 

4. TITLE AND SUBTITLE

An Evaluation of Hydrated Calcium Aluminate Compounds as Energy Storage Media

5. AUTHOR(S)

John B. Ings and Paul W. Brown

6. PERFORMING ORGANIZATION (If joint or other thon NBS, see instructions)

7. Contracd Grant No.

NATIONAL BUREAU OF STANDARDS

DEPARTMENT OF COMMERCE

WASHINGTON, D.C. 20234

8. Type of Report \& Period Covered

9. SPONSORING ORGANIZATION NAME AND COMPLETE ADDRESS (Street. City, State, ZIP)

U.S. Department of Energy

Office of Solar Heat Technologies

Conservation and Renewable Energy

Washington, DC 20885

10. SUPPLEMENTARY NOTES

Document describes a computer program; SF-185. FIPS Software Summary, is attached.

11. ABSTRACT (A 200-word or less factual summary of most significant information. If document includes a significant bibliography or literature survey. mention it here)

Calcium aluminate hydrates and calcium aluminate hydrates containing other ions were investigated to determine the feasibility of their utilization as energy storage media. A series of these compounds were fabricated and analyzed for purity. The energy liberated on hydration of each compound was measured using conduction calorimetry, and the dehydration temperature was measured using differential scanning calorimetry. Of the compounds investigated, $3 \mathrm{CaO} \cdot \mathrm{Al}_{2} \mathrm{O}_{3} \cdot 3 \mathrm{CaSO}_{4} \cdot 32 \mathrm{H}_{2} \mathrm{O}$ liberated the largest amount of energy upon rehydration. Initially, this value was about $100 \mathrm{cal} / \mathrm{gram}$. However, after 18 cycles of hydration and dehydration this value drops to about $70 \mathrm{cal} / \mathrm{gram}$.

12. KEY WORDS (Six to twelve entries; alphabetical order: capitalize only proper names; and separate key words by semicolons)

Calcium-aluminum hydrates; calorimetry; dehydration; energy storage; rehydration; solar.

13. AVAILABILITY

[X] Unlimited

For Official Distribution. Do Not Release to NTIS

Order From Superintendent of Documents, U.S. Government Printing Office, Washington, D.C. 20402.

— Order From National Technical Information Service (NTIS), Springfield. VA. 22161
14. NO. OF PRINTED PAGES

$$
15
$$

15. Price

$\$ 6.00$ 


